\title{
Anxiety and Psychological Well-Being Levels of Faculty of Sports Sciences Students
}

\author{
Aygül Çağlayan Tunç ${ }^{1}$ \\ ${ }^{1}$ Konya, Turkey \\ Correspondence: Aygül Çağlayan Tunç, Konya, Turkey. E-mail: aygulcaglayan@hotmail.com
}

Received: January 3, 2020

Accepted: February 10, 2020

Online Published: April 18, 2020

doi:10.5539/ies.v13n5p117

URL: https://doi.org/10.5539/ies.v13n5p117

\begin{abstract}
The aim of the study is to examine the anxiety and psychological well-being levels of the students of the sports sciences. The study is in relational screening model. 210 university students participated in the study with simple random sampling method. Collection of data; Anxiety assessment scale and psychological well-being scale were used. Information was collected from the participants about gender, whether to do active sports or not, and income level. Data analysis was done with SPSS 22 package program. Skewness and kurtosis values are in normal distribution. Independent sample $t$ test was used in binary comparisons and Anova test was used in more than two comparisons. Pearson correlation test was used in the correlation analysis. The significance level for all tests is $\alpha=0.05$. Participants have moderate anxiety. According to gender, women's anxiety level is higher than men's. There was a significant difference in anxiety psychic subscale and total score. In anxiety, somatic sub-dimension and psychological well-being, no significant difference was found in terms of gender. $(\mathrm{P}<0.05)$. According to whether to do active sports; There is no significant difference for anxiety and psychological well-being ( $p>0.05)$. According to the economic level; Significant differentiation was found in anxiety somatic sub-dimension and total score. Those with bad income were found to have high anxiety and low psychological well-being than those with good and moderate levels $(\mathrm{p}<0.05)$.
\end{abstract}

Keywords: anxiety, psychological well-being, university students

\section{Introduction}

\subsection{Statement of the Problem}

University years are an important period for all students. In this period when the individual can realize himself and reveal his potential, the youth face some problems. This situation sometimes causes tension and anxiety in students.

\subsection{Purpose and Questions of the Study}

The aim of the study is to examine the anxiety and psychological well-being levels of the students of the sports sciences.

- Do the levels of anxiety and psychological well-being differ according to gender?

- Do anxiety and psychological well-being levels differ depending on whether or not you are actively involved in sports?

- Do the levels of anxiety and psychological well-being differ according to income level?

- Is there a relationship between anxiety and psychological well-being?

\subsection{Significance of the Study}

Sometimes anxiety symptoms of university students and sometimes normal individuals become permanent. If it comes to a level that will hinder their daily lives, this situation can be defined as general anxiety disorder (Biddle \& Mutrie, 2008). If people perceive some external stimulants as threats, the biological and psychological balance may be impaired. Some psychological diseases may develop (Aslan \& Ağıroğlu, 2018). Therefore, instead of eliminating anxiety, it is necessary to manage the stress brought by modern life and reach the level of psychological well-being. It is important for university students to reach this awareness. 


\subsection{Literature Review}

Anxiety is the tension caused by anxiety, restlessness and uncertainty caused by the internal conflict of people (Hill, 1991). Anxiety is a human-specific mood that exists in the structure of people since existence. The state of tension experienced by individuals may vary from mild to panic. Some symptoms can be observed depending on the level of tension of anxious people. An uncertain cause of anxiety and anxiety leads to the need to accelerate heart rate, increase muscle tone, sweat, grow pupils, and urinate frequently. It causes feeling thirsty and sometimes difficult to perceive what is happening around. Anxiety is a necessary feeling for people to be protective sometimes in their lives and sometimes to be a driving force. Moderate anxiety is beneficial. Anxiety, which is above the middle level, while increasing attention and courage especially in university students, athletes and sedentary people; it leads to impaired ability to understand, listen, grasp and decide (Bunalt1, 2004).

Sometimes anxiety symptoms of university students and sometimes normal individuals become permanent. If it comes to a level that will hinder their daily lives, this can be defined as general anxiety disorder (Biddle \& Mutrie, 2008). If people perceive some external stimulants as threats, the biological and psychological balance may be impaired.

Some psychological diseases may develop (Selve, 1982). Therefore, instead of eliminating anxiety, it is necessary to manage the stress brought by modern life and reach the level of psychological well-being.In the 19th century, the science of psychology moved away from negative psychological issues and turned to positive issues. In particular, humanists have emphasized the issues that support psychological well-being. After the 1930s, the importance given to people has increased. The idea that the happiness of the individual is paramount has come to the fore (Güleç, 2016). Research has not been done on negativities. It has focused on positive features for the development and change of people (Hamurcu, 2011).

Psychological well-being is one of these issues. According to Huppert (2009) psychological well-being is related to a good life. But it is not possible for people to be in constant well-being. It is necessary to accept the negativities as a part of life. Therefore, in order to avoid good mood and anxiety, individuals can increase their social relationships, apart from routine work, and benefit from physical activity for a healthy body and soul.

Physical activity has a positive effect on mood, anxiety and general health (Ströhle, 2009). Men and women have different characteristics in terms of physical and sportive performance (Genç, Tutkun, Güven, \& Acar, 2019). Exercise has a protective effect against metabolic diseases (Dalaman, 2017). In addition, it is known that nutrition and exercise positively affect the intestinal flora (Genç, Tutkun, Acar, \& Zorba, 2020). In a study, it is emphasized that physical activity programs reduce chronic anxiety. It has been reported that moderate intensity exercise reduces temporary anxiety. In addition, it has been reported to contribute to psychological well-being (Meydanlığlu, 2015). In order for students to spend their education and training life healthy and productive, they should be ensured to participate in some sports activities. Awareness-raising seminars and trainings can be given to students and faculty at the university on this subject (Yiğit \& Karakaya, 2010).

In this study, anxiety and psychological well-being levels of students of the faculty of sports sciences were investigated. In the literature review, it was found that psychological well-being and anxiety did not work together in student groups with high physical activity level. Therefore, this research is thought to contribute to the literature.

\section{Method}

The study was designed according to the relational screening model. A total of 210 university students, 99 females and 111 males, who were studying at Gazi University Faculty of Sport Sciences and selected among volunteer students by simple random sampling method, participated in the study. Independent variables that are thought to be effective in research in collecting data; Questions prepared by the researcher about gender, active sports, income level were used. In addition, to determine the levels of anxiety and psychological well-being of students; Hamilton anxiety assessment scale was used. The scale consists of 14 items. (It was used to measure anxious temperament, tension, fears, insomnia, intellectual skills, depressive temperament, psycho-motor and sensory symptoms, and anxiety level. (Yazıcı, Demir, Tanrıverdi, Karaağaoğlu, \& Yolaç, 1998), adapted it to Turkish. To measure psychological well-being, it was adapted to Turkish (Telef \& Ergun, 2013). 8 questions psychological well-being scale was used Analysis of data, SPSS program, Skewness and kurtosis values showed normal distribution, Independent sample t test in binary comparisons, Anova test in more than two comparisons. Correlation test was used and the significance level for all tests was $\alpha=0.05$.

\subsection{Research Model}

The study was designed according to the relational screening model. This model is used to determine the change 
that takes place at the same time in the variables and the level of this change (Karasar, 2012).

\subsection{Participant (Subject) Characteristics}

The sample of the research; It consists of 210 university students (99 females and 111 males) selected by simple random sampling method among students studying at Gazi University Faculty of Sport Sciences in 2019-2020 academic year.

\subsection{Criteria for Participation}

Doing regular sports at least 3 days a week. Becoming at the age of 18 and over.

\subsection{Data Collection Tools}

\subsubsection{Personal Information Form}

The independent variables (gender, whether to do active sports, income level), which are considered to be effective in the research, were created by the researcher to collect information about students studying in the faculty of sports sciences.

\subsubsection{Hamilton Anxiety Rating Scale}

Hamilton anxiety assessment scale was used. The scale consists of 14 items. (Anxious temperament, tension, fears, insomnia, intellectual skills, depressive temperament, psycho-motor and sensory symptoms and anxiety level were used to measure the scale (Yazıc1 et al., 1998) in Turkish. Questions 1,2,3,5,6 at the scale measure psychic features; Questions 4,7,8,9,10,11,12,13 measure the features in the somatic sub-dimension. Minimum 0 and maximum 56 points are obtained from the scale. 0-17 points indicate "mild anxiety", 18-25 points "moderate anxiety", 26-30 points "serious anxiety." In our study, Cronbach Alpha internal consistency coefficient was calculated as 0.86 .

\subsubsection{Psychological Well-Being Scale.}

Psychological well-being scale is used to measure the psychological well-being level of individuals. He adapted the scale (Telef, 2013) to Turkish. The scale does not have sub-dimensions, there are eight questions. All questions in the scale contain positive statements. Questions are answered in seventh grade. A minimum score of 8 and a maximum of 56 can be obtained from the scale. The high score indicates that the participants have a psychological power and resource. Cronbach Alpha internal consistency coefficient was calculated as 0.80 . In this study, Cronbach Alpha internal consistency coefficient of the Psychological Well-Being Scale was calculated as 0.860 .

\subsection{Statistics and Data Analysis}

The data were analyzed in computer environment with SPSS program, firstly, normal distribution values related to the type of tests to be used were analyzed. Skewness and kurtosis values were found to show normal distribution and independent sample $t$ test was used in binary comparisons and Anova test was used in more than two comparisons. Pearson correlation test was used for correlation analysis. The significance level $\alpha=0.05$ was used for all tests.

\section{Results}

Table 1. Socio-demographic characteristics of the participants

\begin{tabular}{ccc}
\hline & $\mathrm{n}$ & $\%$ \\
\hline Gender & & \\
\hline Female & 99 & 47.1 \\
\hline Male & 111 & 52.9 \\
\hline Active sports & & \\
\hline Yes & 200 & 95.1 \\
\hline No & 10 & 4.8 \\
\hline Economic Level & & \\
\hline Good & 45 & 21.4 \\
\hline Middle & 142 & 67.6 \\
\hline Poor & 23 & 11.0 \\
\hline Total & 210 & 100 \\
\hline
\end{tabular}


When the socio-demographic characteristics of the participants are examined, it is seen that $52.9 \%$ of them are men and $47.1 \%$ are women, the majority of the participants $(95.1 \%)$ are active in sports and evaluate themselves in terms of their economic level.

Table 2. Mean anxiety and psychological well-being of the participants

\begin{tabular}{ccccc}
\hline & $\bar{X}$ & ss & $\min$ & $\max$ \\
\hline Hamilton Psychic & 6.59 & 3.79 & 0 & 19 \\
Hamilton Somatic & 7.98 & 6.41 & 0 & 28 \\
Hamilton Total & 14.58 & 9.28 & 0 & 47 \\
Psychological Well-being & 43.84 & 8.54 & 10 & 56 \\
\hline
\end{tabular}

When the mean scores of the Hamilton anxiety assessment scale were examined, the mean psychic sub-dimension was 6.59 , the mean somatic sub-dimension was 7.98 , and the mean total score was 14.58 . When the total mean score of anxiety of the participants is examined, it can be said that they are at the level of "mild anxiety". The mean score of psychological well-being was found to be 43.84 .

Table 3. Anxiety and psychological well-being scores by gender

\begin{tabular}{|c|c|c|c|c|c|c|}
\hline & Gender & $\mathrm{n}$ & $\bar{X}$ & ss & $\mathrm{t}$ & $\mathrm{p}$ \\
\hline \multirow{2}{*}{ Hamilton Psychic } & Female & 99 & 7.31 & 3.71 & \multirow{2}{*}{2.623} & \multirow{2}{*}{$.009^{*}$} \\
\hline & Male & 111 & 5.95 & 3.77 & & \\
\hline \multirow{2}{*}{ Hamilton Somatic } & Female & 99 & 8.99 & 6.31 & \multirow{2}{*}{1.960} & \multirow{2}{*}{.051} \\
\hline & Male & 111 & 7.17 & 6.43 & & \\
\hline \multirow{2}{*}{ Hamilton Total } & Female & 99 & 16.21 & 8.87 & \multirow{2}{*}{.704} & \multirow{2}{*}{$.016^{*}$} \\
\hline & Male & 111 & 13.12 & 9.43 & & \\
\hline \multirow{2}{*}{ Psychological Well-being } & Female & 99 & 43.10 & 9.38 & \multirow{2}{*}{.117} & \multirow{2}{*}{.233} \\
\hline & Male & 111 & 44.51 & 7.70 & & \\
\hline
\end{tabular}

$* \mathrm{p}<0.05$.

When the mean scores of the students of the Faculty of Sport Sciences were analyzed according to gender, it was seen that there was a significant difference in the psychic sub-dimension and total score of the Hamilton anxiety scale. Mean anxiety score of women is higher than men. There was no significant difference in Hamilton somatic subscale and psychological well-being scores.

Table 4. Anxiety and psychological well-being scores compared to active sports

\begin{tabular}{|c|c|c|c|c|c|c|}
\hline & Active Sports & $\mathrm{n}$ & $\overline{\bar{X}}$ & ss & $\mathrm{t}$ & $\mathrm{p}$ \\
\hline \multirow{2}{*}{ Hamilton Psychic } & Yes & 200 & 6.64 & 3.67 & \multirow{2}{*}{.556} & \multirow{2}{*}{.592} \\
\hline & No & 10 & 5.60 & 5.89 & & \\
\hline \multirow{2}{*}{ Hamilton Somatic } & Yes & 200 & 7.99 & 6.24 & \multirow{2}{*}{.063} & \multirow{2}{*}{.951} \\
\hline & No & 10 & 7.80 & 9.70 & & \\
\hline \multirow{2}{*}{ Hamilton Total } & Yes & 200 & 14.64 & 8.95 & \multirow{2}{*}{.257} & \multirow{2}{*}{.803} \\
\hline & No & 10 & 13.40 & 15.10 & & \\
\hline \multirow{2}{*}{ Psychological Well-being } & Yes & 200 & 44.01 & 8.22 & \multirow{2}{*}{.783} & \multirow{2}{*}{.453} \\
\hline & No & 10 & 40.60 & 13.64 & & \\
\hline
\end{tabular}

When the mean scores of the scale were examined according to whether the students of the Faculty of Sport Sciences did active sports, it was seen that the average scores of the hamilton anxiety scale, psychic and somatic subscale, total score and psychological well-being scale did not differ significantly according to whether or not they did active sports. 
Table 5. Anxiety and psychological well-being scores according to economic level

\begin{tabular}{|c|c|c|c|c|c|c|c|c|}
\hline & Economic Level & & $\mathrm{n}$ & $\bar{X}$ & ss & $\mathrm{F}$ & $\mathrm{p}$ & Significant difference \\
\hline \multirow{3}{*}{ Hamilton Psychic } & $\mathrm{A}$ & Good & 45 & 6.33 & 4.02 & \multirow{3}{*}{2.527} & \multirow{3}{*}{.082} & \\
\hline & $\mathrm{B}$ & Middle & 142 & 6.40 & 3.66 & & & \\
\hline & $\mathrm{C}$ & $\mathrm{Bad}$ & 23 & 8.26 & 3.88 & & & \\
\hline \multirow{3}{*}{ Hamilton Somatic } & $\mathrm{A}$ & Good & 45 & 7.33 & 6.64 & \multirow{3}{*}{5.634} & \multirow{3}{*}{$.004 *$} & \multirow{3}{*}{$\begin{array}{l}\mathrm{C}>\mathrm{A} \\
\mathrm{C}>\mathrm{B}\end{array}$} \\
\hline & $\mathrm{B}$ & Middle & 142 & 7.51 & 5.93 & & & \\
\hline & $\mathrm{C}$ & $\mathrm{Bad}$ & 23 & 12.13 & 7.56 & & & \\
\hline \multirow{3}{*}{ Hamilton Total } & $\mathrm{A}$ & Good & 45 & 13.68 & 9.86 & \multirow{3}{*}{5.275} & \multirow{3}{*}{$.006^{*}$} & \multirow{3}{*}{$\begin{array}{l}\mathrm{C}>\mathrm{A} \\
\mathrm{C}>\mathrm{B}\end{array}$} \\
\hline & $\mathrm{B}$ & Middle & 142 & 13.92 & 8.53 & & & \\
\hline & $\mathrm{C}$ & $\mathrm{Bad}$ & 23 & 14.58 & 9.28 & & & \\
\hline \multirow{3}{*}{ Psychological Well-being } & $\mathrm{A}$ & Good & 45 & 45.97 & 9.56 & \multirow{3}{*}{7.172} & \multirow{3}{*}{$.001^{*}$} & \multirow{3}{*}{$\begin{array}{l}\mathrm{A}>\mathrm{C} \\
\mathrm{A}>\mathrm{B}\end{array}$} \\
\hline & $\mathrm{B}$ & Middle & 142 & 44.11 & 7.30 & & & \\
\hline & $\mathrm{C}$ & $\mathrm{Bad}$ & 23 & 38.04 & 11.10 & & & \\
\hline
\end{tabular}

$* \mathrm{p}<0 . \overline{05}$

When the anxiety and psychological well-being scores were evaluated according to the income level of the students, it was seen that there was no difference in the Hamiltonian psychic score average. A significant difference was found in the somatic and total score of Hamilton scale according to income level. According to the post-hoc test on the difference between the groups, the difference is between the good-middle and bad groups, that is, there is a difference between the income level perception of the good and middle and the bad ones and the anxiety level of the people with bad economic level is higher. When psychological well-being score environments are examined, it is seen that there is a similar meaningful differentiation and that the difference is between the good-middle and bad groups, and the psychological well-being scores of the people with a poor income level are lower than the good-moderate ones and this difference is significant.

Table 6. Investigation of the relationship between anxiety and psychological well-being scores

\begin{tabular}{cccc}
\cline { 2 - 3 } Hamilton Psychic & $\mathrm{r}$ & $-333^{* *}$ \\
& $\mathrm{p}$ & .000 \\
\cline { 2 - 4 } Hamilton Somatic & $\mathrm{r}$ & $-.301^{* *}$ \\
& $\mathrm{p}$ & 000 \\
\hline \multirow{2}{*}{ Hamilton Total } & $\mathrm{r}$ & $-.344^{* *}$ \\
& $\mathrm{p}$ & 000 \\
\hline
\end{tabular}

$* \mathrm{p}<0.01$.

When the relationship between the psychic and somatic subscale and total score of the Hamilton anxiety assessment scale and the psychological well-being scale score is evaluated, it is seen that there is a statistically significant and low level relationship between the Hamilton anxiety scale and the psychological well-being scale in terms of the subscale and total score.

\section{Discussion}

In this study, which examines the relationship between the anxiety and psychological well-being levels of the students of the sports sciences, the gender, whether or not to do sports and economic level variables were examined, and the findings were discussed by comparing them with the literature.The demographic characteristics of the students participating in the study are $52.9 \%$ male and $47.1 \%$ female. The participants (95.1\%) of the research do regular sports. It is seen that they evaluate their economic levels at an intermediate level.When the scale scores of the students of the Faculty of Sport Sciences are analyzed, it is seen that there is a significant difference in the Hamilton anxiety scale psychic subscale and total score. The anxiety point averages of women are higher than the men. There was no significant difference in anxiety somatic sub-dimension and psychological well-being scale mean scores.Accordingly, it was found that women were more anxious than men, and men had lower anxiety levels than women. There is no difference between genders in psychological well-being levels. When the literature is examined, similar results are frequently encountered (Helvac1 \& 
Hocaoğlu 2016), in this study, reached the conclusion that the prevalence of anxiety level throughout the life of women is always higher than that of men, the level of anxiety of women and the level of anxiety of men (30.5\%) was found (19.2\%) (Yonkers, Allsworth, Warshaw, Shea, \& Keller, 1998; Kendler, Neale, Kessler, Heath, \& Eaves, 1992). In their study, they concluded that the prevalence of anxiety in women is higher than that of men (Shear \& Mammen, 1995), in his research, linked the reason for the anxiety disorder rate in women to be higher than men in menstural periot. They reached the conclusion that anxiety level increased in the pre-menstrual period causes this difference between the sexes. Likewise, Norton, McLeod, Guertin, and Hewitt (2001), in their study using anxiety scale, they concluded that anxiety was more prominent in female participants than in men in cognitive and somatic symptoms (Akın \&Şentürk, 2012) different from our study; in a study where individuals' happiness and well-being levels were examined, men were found to have more happiness and psychological well-being than women. In our study, there is no difference between genders in terms of psychological well-being. Ryff and Singer (2008) concluded that psychological well-being has a negative relationship in terms of symptoms such as anxiety, anger and anxiety in humans.According to the scale scores averaged according to whether the students of the Faculty of Sport Sciences do active sports, it is seen that the anxiety scale psychic and somatic sub-dimension, total score and psychological well-being scale scores do not differ significantly according to whether they do active sports or not.In this context, students studying in the faculty of sports sciences are more active and active than students studying in other departments. In addition, the presence of physical activity courses in the curriculum did not cause any difference between students who actively do sports and students who do not do active sports. It is seen that the majority of the participants both attend school and do active sports. For this reason, there was no difference between the participants according to the variable of whether to do sports regularly or not.

Ölçülü, Vatansever, Özcan, Çelik, and Paktaş (2015) concluded that there is no statistically significant difference between the anxiety scores of female and male students in their study with university students with different levels of physical activity. Thome and Espelage (2004) emphasize that there is a positive relationship between university students' sports and their psychological health and psychological well-being.In another study conducted with students studying at the university, aerobic exercise, resistance exercise and physical activity program were given to the students who were assigned to the control group, and in the findings obtained from the study, it was observed that the level of anxiety decreased in the students who applied aerobic exercise (Balkin, Tietjen-Smith, Caldwell, \& Yu-Pei, 2007). In a study examining exercise anxiety and different variables, anxiety levels were found to be significantly lower compared to non-sports participants (Canan \& Ataoğlu, 2010). When the anxiety and psychological well-being scores of the students are evaluated according to their income level, there is no difference in the average of anxiety psychic score. There was a significant difference in anxiety scale somatic sub-dimension and total score according to income level. Anxiety level was found to be higher in the participants with low income perception than those with good and middle income levels. Similarly, there is a statistically significant differentiation in psychological well-being scores. Psychological well-being scores of people with bad income levels were found to be significantly lower than those with good and moderate income levels.In this context, it is seen that the economic status of the participants has an impact on psychological well-being and anxiety level. It is observed that people with poor economic level are negatively affected by this situation and their anxiety levels increase, and their psychological well-being levels decrease. The economic level is a tool for individuals to achieve their goals. Achieving these goals can sometimes be difficult when the income level drops. This can create tension both in university students and in normal individuals. For this reason, students with weak economic levels have high anxiety and low psychological well-being. When the literature on the subject is examined (Kessler et al., 1994), in this research; there is a strong relationship between social and economic status and anxiety level in humans. In a study (Kasser \& Ahuvia, 2002) with university students in Singapore, the relationship between money, image and value orientation was examined, and it was concluded that the economy caused symptoms of anxiety and unhappiness in students. Tatlıoğlu (2015), in a study with university students, examined the relationship between materialistic values and psychological well-being; The fact that the monthly money spent is more or less does not make a difference in the level of psychological well-being, he found the result. There are studies which have been concluded that the money spent for the good of others on the economy gives more permanent happiness and psychological well-being than the money spent individually (Dunn, Aknin, \& Norton, 2008). So, in this study, being able to spend money for the good of others may require individuals to meet their own needs at a certain level. Therefore, it can be thought to be similar to the results of our study. Good economic level can increase psychological well-being and happiness. It can be interpreted that it can reduce anxiety and tension. When the relationship between Hamilton anxiety evaluation scale psychic and somatic subscale and total score and psychological well-being scale score is evaluated, it is seen that there is a statistically significant and low level relationship 
between anxiety scale and psychological well-being scale in terms of sub-dimension and total score.Both conflicting and similar results were found in the literature. It can be thought that this difference arises from the sample group, cultural differences and many uncontrollable factors affecting the psychological state. In addition, it may be a point of view to encounter various results in the literature and evaluate anxiety and psychological well-being in different dimensions.In the research, it is normal for mild anxiety to be seen in students. We can link this to the students being physically active. Therefore, at universities, exercise programs should be included in all departments as part of the training. It may be suggested that the courses be carried out within the plan and program.

\section{Conclusion}

All participants had mild anxiety levels. However, women's anxiety levels are higher than men's. There is no difference in psychological well-being and anxiety level in students who do sports or not. Participants with poor economic level have low psychological well-being and higher anxiety levels than those with good and medium levels. While gender and economic level are factors affecting anxiety and psychological well-being, whether the participants do regular sports did not affect the results statistically. There is a need for studies with different sample groups on the subject.In order to generalize the results, studies may be required in different cultures, different age groups and different sample groups. In addition, it is thought that clinical studies with healthy individuals will contribute to the relevant literature.As a suggestion; The findings obtained from the research provide information about the psychological status of university students, especially those with high level of sports activity. of results; It is thought to shed light on researchers, practitioners and literature.

\section{References}

Akın, H. B., \& Şentürk, E. (2012). Bireylerin mutluluk düzeylerinin ordinal lojistik regresyon analizi ile incelenmesi. Öneri Dergisi, 10(37), 183-193.

Aslan, M., \& Ağıroğlu, B. A. (2018). Sınıf öğretmenlerinin yaşadıkları örgütsel stres kaynakları. Cumhuriyet Uluslararası Ĕgitim Dergisi, 7(4), 349-365. https://doi.org/10.30703/cije.430748

Balkin, R. S., Tietjen-Smith, T., Caldwell, C., \& Yu-Pei, S. (2007). The utilization of exerciset odecrease depressive symptoms in young adult women. Adult Span Journal, 6(1), 30-35. https://doi.org/10.1002/j.2161-0029.2007.tb00027.x

Biddle, S. J. H., \& Mutrie, N. (2008). Psychology of Physical Activity: Determinants, Well-Being and Interventions (2nd ed.). New York: Routledge. https://doi.org/10.4324/9780203019320

Bunaltı-Öztürk, M. O. (2004). Ruh sağllğı ve bozuklukları. Ankara: Nobel Tıp Kitabevleri.

Canan, F., \& Ataoğlu, A. (2010). Anksiyete, depresyon ve problem çözme becerisi algısı üzerine düzenli sporun etkisi. Anatolian Journal of Psychiatry, 11, 38-43.

Dalaman, O. (2017). Investigating female pre-service preschool teachers' attitudes towards sport. Educational Research and Reviews, 12(24), 1242-1252. https://doi.org/10.5897/ERR2017.3417

Dunn, E. W., Aknin, L. B., \& Norton, M. I. (2008). Spending money on others promotes happiness. Science, 319(5870), 1687-1688. https://doi.org/10.1126/science.1150952

Genç, A., Tutkun, E., Acar, H., \& Zorba, E. (2020). Investigation of Relation Between Clostridium Colonization and Nutrient Consumption in Intestinal Flora in Athletes and Sedentary Men. Progress in Nutrition, 22(2). https://doi.org/10.23751/pn.v22i2.8292

Genç, A., Tutkun, E., Güven, D., \& Acar, H. (2019). Investigation of the endometrial thickness and estrogen level in athletes and sedentaries. Clinical and Experimental Obstetrics \& Gynecology, 46(1), 123-126.

Güleç, C. (2016). Pozitif ruh sağglı̆̆ı. 3. Baskı Ankara: Arkadaş.

Hamurcu, H. (2011). Ergenlerin Yetkinlik Inançları ve Psikolojik Iyi Oluşlarını Yordamada Psikolojik İhtiyaçlar. Selçuk Üniversitesi Doktora Tezi, Konya.

Helvacı Ç. F., \& Hocaoğlu, Ç. (2016). Major depresif bozukluk tanımı, etyolojisi ve epidemiyolojisi: Bir gözden geçirme. Çağdaş Tip Dergisi, 6(1), 51-66. https://doi.org/10.16899/ctd.03180

Hill, F. (1991). The neurophysiology of acute anxiety: A review of the literature. CRNA, 2, 52-61.

Huppert, F. A. (2009). Psychological well-being: Evidence regarding its causes and consequences. Applied Psychology: Health and Well-Being, 1(2), 137-164. https://doi.org/10.1111/j.1758-0854.2009.01008.x

Karasar, N. (2012). Bilimsel Araştırma Yöntemleri. Ankara: Nobel Yayınları. 
Kasser, T., \& Ahuvia, A. (2002). Materialistic values and well-being in business students. European Journal of Social Psychology, 32(1), 137-146. https://doi.org/10.1002/ejsp.85

Kendler, K., Neale, M., Kessler, R., Heath, A., \& Eaves, L. (1992). The Genetic epidemiology of phobias in women: The interrelationship of agoraphobia, social phobia, situational phobia, and simple phobia. Arch. Gen. Psychiatry, 49, 273-281. https://doi.org/10.1001/archpsyc.1992.01820040025003

Meydanlığlu, A. (2015). Çocuklarda fiziksel aktivitenin biyo-psikososyal yararları. Psikiyatride Güncel Yaklaşımlar, 7(2), 125-135. https://doi.org/10.5455/cap.20140714124129

Norton, G. R., McLeod, L., Guertin, J., \& Hewitt, P. (2001). The growth of anxiety disorders during the 1980s. Journal of Anxiety Disorders, 9, 75-85. https://doi.org/10.1016/0887-6185(94)00029-A

Ölçülü, B., Vatansever, Ş., Özcan, G., Çelik, A., \& Paktaş, Y. (2015). Üniversite öğrencilerinde fiziksel aktivite düzeyi ile depresyon ve anksiyete ilişkisi. Uluslararası Türk Eğitim Bilimleri Dergisi, 4, 294-303.

Ryff, C. D., \& Singer, B. H. (2008). Know thyself and become what you are: A eudaimonic approach to $\begin{array}{lllll}\text { psychological well-being. Journal of Happiness Studies, } & \text { 9(1), }\end{array}$ https://doi.org/10.1007/s10902-006-9019-0

Shear, M., \& Mammen, O. (1995). Anxiety disorders in pregnant and post-partum women. Psychopharmacol Bull, 31, 693-703.

Ströhle, A. (2009). Physical activity, exercise, depression and anxiety disorders. J. Neural Transm, 116, 777-784. https://doi.org/10.1007/s00702-008-0092-x

Tatlıŏlu, K. (2015). Üniversite öğrencilerinin aylık gelir düzeyleri ile psikolojik iyi oluşları arasındaki ilişkinin incelenmesi (Bingöl üniversitesi örneği). Elektronik Sosyal Bilimler Dergisi, 14(55), 1-15. https://doi.org/10.17755/esosder.40308

Telef, B. B., \& Ergün, E. (2013). Lise öğrencilerinin öznel iyi oluşlarının yordayıcısı olarak öz-yeterlik. Kuramsal Ĕ̈itimbilim Dergisi, 6(3), 423-433. https://doi.org/10.5578/keg.5955

Thome, J., \& Espelage, D. (2004). Relations among exercise, coping, disordered eating, and psychological health among college students. Eat Behav, 5, 337-351. https://doi.org/10.1016/j.eatbeh.2004.04.002

Yazıcı, M. K., Demir, B., Tanrıverdi, N., Karaağaoğlu, E., \& Yolaç, P. (1998). Hamilton anksiyete değerlendirme ölçeği, değerlendiriciler arası güvenilirlik ve geçerlilik çalışması. Türk Psikiyatri Dergisi, 9, 114-120.

Yiğit, N., \& Karakaya, O. (2010). Türk Müziği Anasanat Dallarında Koro Eğitimi ve Yönetimi Uygulamaları. Selçuk Üniversitesi Ahmet Keleşoğlu Eğitim Fakültesi Dergisi, 29, 29-47.

Yonkers, K. A. Z. C., Allsworth, J., Warshaw, M., Shea, T., \& Keller, M. B. (1998). Is the course of panic disorder the same in women and men? Am. J. Psychiatry, 155, 596-602. https://doi.org/10.1176/ajp.155.5.596

\section{Copyrights}

Copyright for this article is retained by the author(s), with first publication rights granted to the journal.

This is an open-access article distributed under the terms and conditions of the Creative Commons Attribution license (http://creativecommons.org/licenses/by/4.0/). 